\title{
Service Section
}

\section{Case Law of the Court of Justice of the European Union and the General Court}

\author{
Reported Period 31.08.2016-01.12.2016
}

\section{Lorenzo Squintani}

Assistant professor of European and Economic Law and the

University of Groningen, the Netherlands

l.squintani@rug.nl

\section{Overview of the Judgments}

\section{Showing Some Leniency towards Greece Waste Management Shortcomings}

Judgment of the Court (Fifth Chamber) of 7 September 2016 in Case C-584/14 - Commission v Hellenic Republic

\section{Subject Matter}

This infringement procedure brought against Greece, due to non-compliance with the judgment of the Court in case C-286/o8 Commission v Hellenic Republic, concerns the lack of sufficient measures for managing hazardous waste under Directive 2006/12/Ec. Greece did not dispute the lack of implementing measures, but claimed that it had made progresses. Accordingly, the Commission requested the Court to take account of these progresses while establishing the periodic penalty payment.

1 Judgements and orders not published in ECR have been included in this report only if considered of particular interest for the developemnt of EU environmental law. 


\section{Key Findings}

83 It should be noted in this connection that, even if, in order to ensure full compliance with the Court's judgment, the penalty payment should be payable in its entirety until such time as the Member State has taken all the measures necessary to bring to an end the failure to fulfil obligations established, nevertheless, in certain specific cases, a penalty which takes account of the progress that the Member State may have made in complying with its obligations may be envisaged (judgment of 2 December 2014 in Commission v Greece, C-378/13, E U:c:2014:2405, paragraph 60 and the case-law cited).

92 In the light of all the above considerations, it is necessary to order the Hellenic Republic to pay the Commission, into the 'European Union own resources' account, a penalty payment of EUR 30 ooo for each day of delay in adopting the measures necessary to comply with the judgment of 10 September 2009 in Commission v Greece (C-286/o8, not published, EU:C:2009:543), from the date of delivery of the present judgment until full compliance with the judgment of 10 September 2009 in Commission v Greece (C 286/08, not published, EU:C:2009:543). That amount is divided into three parts, corresponding to the three heads of claim invoked by the Commission and is the equivalent, with respect to the first head of claim, to $10 \%$ of the total amount of the penalty payment, namely EUR 3 ooo, with respect to the second head of claim, to $45 \%$ of that amount, namely EUR 13500 , as well as with respect to the third head of claim, which, as regards the proper management of so-called 'historical' waste, will be subject to a six-monthly reduction as a pro rata of the volume of that waste the management of which was in compliance. That reduction is limited to $50 \%$ of the amount of the penalty payment corresponding to that head of claim, that is to say EUR $675^{\circ}$.

Building upon the Invalidity of Decision 2013/448/E U: The Borealis II Case

Judgment of the General Court (Sixth Chamber) of 8 September 2016 in Case C-180/15 - Borealis $A B$ and Others

\section{Subject Matter}

This case concerns a preliminary reference deriving from a case brought by the operators of several ETS installations, among which Borealis AB, against a decision of the Swedish Environmental Protection Agency setting the amount of 
greenhouse gas emissions allowances allocated for free to these installations under Decisions 2011/278/EU and 2013/448/EU. Following a line of arguments similar to that bought forward in the previous Borealis Case, Joined Cases $C-191 / 14$, C-192/14, C-295/14, C-389/14 and C-391/14 to C-393/14 (See JEEPL 2016/3-4), the claimants in this case sought the annulment of both $E U$ Decisions.

\section{Judgment}

1. Examination of the first, second and thirteenth questions has revealed no factor of such a kind as to affect the validity of Commission Decision 2011/278/EU of 27 April 2011 determining transitional Union-wide rules for harmonised free allocation of emission allowances pursuant to Article 10a of Directive 2003/87/EC of the European Parliament and of the Council.

2. Examination of the fifth question referred has revealed no factor of such a kind as to affect the validity of Annex I to Decision 2011/278.

3. Article 4 of, and Annex II to, Commission Decision 2013/448/EU of 5 September 2013 concerning national implementation measures for the transitional free allocation of greenhouse gas emission allowances in accordance with Article 11(3) of Directive 2003/87/EC of the European Parliament and of the Council are invalid.

4. The temporal effects of the declaration of invalidity of Article 4 of, and Annex II to, Decision 2013/448 are limited so that, first, that declaration does not produce effects until 10 months following the date of delivery of the judgment in Borealis Polyolefine and Others (C-191/14, C-192/14, C-295/14, C-389/14 and C-391/14 to C-393/14, EU:C:2016:311), so as to enable the European Commission to adopt the necessary measures and, second, measures adopted during that period on the basis of the invalidated provisions cannot be called into question.

5. Article 10a of Directive 2003/87/EC of the European Parliament and of the Council of 13 October 2003 establishing a scheme for greenhouse gas emission allowance trading within the Community and amending Council Directive 96/61/EC as amended by Directive 2009/29/EC of the European Parliament and of the Council of 23 April 2009, and Article 10(1) to (3) and (8) of Decision 2011/278 must be interpreted as permitting, in order to avoid a double allocation, non-allocation of allowances to a heat benchmark sub-installation when it exports, to private households, heat which it has recovered from a fuel benchmark sub-installation.

6. Article $10(8)$ of Decision $2011 / 278$ must be interpreted as precluding free greenhouse gas emission allowances being allocated to an operator for 
the consumption, in a heat benchmark sub-installation, of heat taken into account in connection with a fuel benchmark sub-installation.

7. Article 7 of, and Annex IV to, Decision 2011/278 must be interpreted as allowing a Member State, when collecting the data covered by those provisions, not to take into account all the emissions related to the heat production exported by a heat benchmark sub-installation to private households in order to avoid double counting.

8. Article 10a(1) and (4) of Directive $2003 / 87$, as amended by Directive 2009/29, and Article 10(3) of Decision 2011/278 must be interpreted as permitting the non-allocation of additional free greenhouse gas emission allowances related to the production of measurable heat by burning waste gases generated by a hot metal benchmark installation, when the amount of greenhouse gas emission allowances determined based on the heat benchmark is lower than the median annual historical emissions related to the production of that heat.

9. Article 7 of, and Annex IV to, Decision 2011/278 must be interpreted as not precluding a Member State, when collecting the data covered by those provisions, from adjusting the figures obtained by the Member State so that the greenhouse gas emissions attributable to the combustion of waste gases by a heat benchmark sub-installation are equivalent to those from the combustion of natural gas, in so far as a product benchmark takes account of emissions linked to the production of waste gases.

10. Article 3(c), of Decision 2011/278 must be interpreted as meaning that the concept of 'heat benchmark sub-installation' includes the activity of exporting the measurable heat from an installation subject to the greenhouse gas emissions trading system to a steam network when the latter network can be qualified as an 'installation or other entity not covered by the Union scheme'.

\section{On the E Ts Installation Operator Obligation to Provide Information}

Judgment of the Court (Sixth Chamber) of 8 September 2016 in Case C-461/15 - E.oN Kraftwerke GmbH

\section{Subject Matter}

This case concerns a preliminary ruling in a case between a German energy producer and the German emissions allowances trading office, about the information 
that energy producers should provide to the national authority under German law implementing Decision 2011/278/EU determining trans-national Community wide rules for harmonised free allocation of emission allowances pursuant Article 1oa of the E TS Directive. The dispute concerned whether under the Directive operators to provide information relating to all planned or effective changes to the capacity, activity level and operation of an installation, without limiting that requirement solely to information relating to changes that would affect the allocation.

\section{Key Findings}

32 On the other hand, Article 24(1) of Decision 2011/278, which refers to all relevant information concerning such changes, does not limit the operators' obligation of communication solely to cases in which those changes have an impact on the free allocation of emission allowances.

37 In that context, as recalled in paragraph 27 above, the Member States must ensure that the data collected from the operators and used for allocation purposes is complete and consistent and presents the highest achievable accuracy. It is therefore for the Member States to determine themselves what relevant information for the competent authorities must be collected from the operators.

40 In the light of the above considerations, the answer to the questions referred for a preliminary ruling is that Article 24(1) of Decision 2011/278 must be interpreted as not precluding a Member State from requiring undertakings which, being subject to the greenhouse gas emission allowance trading obligation within the $\mathrm{EU}$, receive a free allocation of those allowances to provide information relating to all planned or effective changes to the capacity, activity level and operation of an installation, without limiting that requirement solely to information relating to changes that would affect the allocation.

\section{On the Difference between Medium and Large Enterprises under Regulation (EC) No 1907/2006}

Judgment of the General Court (Sixth Chamber) of 15 September 2016 in Cases T-620/13 - Marchi Industriale SpA

\section{Subject Matter and Judgment}

This case concerns an action for annulment brought by Marchi Industriale, who had registered several substances under the REACH Regulation, against the 
decision of ECHA establishing that the claimant should be considered as being a large enterprise under the Regulation and hence pay the difference between the fees originally paid and the fees ultimately due as well an invoice of EUR 19900 for payment of the administrative charge.

The Court dismissed the action.

\section{Let's talk about the Emissions from the Aberthaw Power Station}

Judgment of the Court (Seventh Chamber) of 21 September 2016 in Case C-304/15 - European Commission v United Kingdom

\section{Subject Matter}

This case concerns an infringement procedure brought against the United Kingdom for wrongful application of the Large Combustion Plans Directive to the Aberthaw Power Station. The dispute concerns the limit value for nitrogen dioxide applied to the power station. Rather than $500 \mathrm{mg} / \mathrm{Nm}_{3}$, the United Kingdom applied the more relaxed limit value of $1200 \mathrm{mg} / \mathrm{Nm}_{3}$, which Note (3) to the Directive envisages only under specific conditions, which, according to the Commission, the Aberthaw Power Station does not fulfil. According to the United Kingdom, such a Note had been inserted to cover specifically the Aberthaw Power Station and hence it should be interpreted in a flexible manner.

\section{Key Findings}

37 It follows from this, as stated by the Advocate General in point 29 of his Opinion, that, by analogy, Note (3) must be interpreted as meaning that the reference period for compiling the data to verify that the plants concerned continue to operate in conformity with the provisions of Directive $2001 / 80$ is identical to that permitting a determination whether a plant did or did not qualify for the derogation contained in that footnote, namely one year.

44 As suggested by the Advocate General in points 27 to 30 of his Opinion, Note (3) must be interpreted as meaning that the $10 \%$ threshold to which it refers indicates that the coal used by a plant must have an average VMC of less than $10 \%$.

53 In those circumstances, it must be held that by failing correctly to apply Directive 2001/80 to Aberthaw PS, the United Kingdom has failed to fulfil its obligations under Article 4(3) of that directive, read in conjunction with Part A of Annex VI thereto. 


\section{Follow up to the Invalidity of Decision 2013/448/EU: The Borealis Progeny}

Judgment of the Court (Sixth Chamber) of 26 October 2016 in Case C-506/14 Yara Suomi Oy and Others

\section{Subject Matter}

This case concerns a preliminary reference made in a case pending between four ETS operators, among which Yara Suomi and Borealis, against the decision of the Finnish Minister for Labour and Economy establishing the allocation of free allowances to the claimants. Following the line of arguments made in the Borealis Case, Joined Cases $C_{-191 / 14,} C_{-192 / 14}, C_{-295 / 14}, C_{-389 / 14}$ and $C_{-391 / 14}$ to $C_{-393 / 14}$ (see JEEPL 2016/3-4) the claimants challenges the validity of Decisions 2011/278/EU and 2013/448/EU which served as basis for the contested Finnish decision.

\section{Judgment}

1. Examination of the third and fourth questions has revealed no factor of such a kind as to affect the validity of Article 15(3) of Commission Decision 2011/278/EU of 27 April 2011 determining transitional Union-wide rules for harmonised free allocation of emission allowances pursuant to Article 10a of Directive 2003/87/EC of the European Parliament and of the Council.

2. Examination of the sixth and seventh questions has revealed no factor of such a kind as to affect the validity of Annex I to Decision 2011/278.

3. Examination of the fifth question referred has revealed no factor of such a kind as to affect the validity of the first subparagraph of Article 10(9) of Decision 2011/278.

4. Article 4 of, and Annex II to, Commission Decision 2013/448/EU of 5 September 2013 concerning national implementation measures for the transitional free allocation of greenhouse gas emission allowances in accordance with Article 11(3) of Directive 2003/87/EC of the European Parliament and of the Council are invalid.

5. The temporal effects of the declaration of invalidity of Article 4 of, and Annex II to, Decision 2013/448 are limited so that, first, that declaration does not produce effects until 10 months following the date of delivery of the judgment in Borealis Polyolefine and Others (C-191/14, C-192/14, C-295/14, C-389/14 and C-391/14 to C-393/14, EU:C:2016:311), so as to enable the European Commission to adopt the necessary measures and, 
second, measures adopted during that period on the basis of the invalidated provisions cannot be called into question.

\section{On the Notion of Plans and Programmes under the SEA Directive}

Judgment of the Court (Second Chamber) of 27 October 2016 in Case C-29o/15 - Patrice D'Oultremont and Others

\section{Subject Matter}

This case concerns a preliminary reference made by the Belgian Council of State during a dispute between among others Mr. Patrice D'Oultremont and the Wallon Region against an order of the latter establishing sector-specific conditions for wind turbines having a total power of less than $0.5 \mathrm{MW}$ as regards their impact assessment. According to the claimants this order was set in breach of the SEA Directive. According to the Council of State, case Terre Wallonne and InterEnvironnement Wallonie, Joined Cases $C-105 / 09$ and $C-110 / 09$, did not provide enough guidance to establish whether the contested order should be considered a plan or programme under the Directive. Accordingly, the Council of State referred the matter to the Court of Justice.

\section{Key Findings}

$5^{2}$ In that regard, it should be noted that it is apparent from the actual wording of Article 2(a), first indent, of that directive, borne out by the case-law referred to in paragraph 49 of the present judgment, that the notion of 'plans and programmes' can cover normative acts adopted by law or regulation.

53 Moreover, as the Advocate General stated in point 70 of her Opinion, Directive 2001/42 differs from the Aarhus Convention and the Kiev Protocol inasmuch as that directive does not contain any special provisions in relation to policies or general legislation that would call for them to be distinguished from 'plans and programmes'.

54 It follows from all of the foregoing that the answer to the question referred is that Articles 2(a) and 3(2)(a) of Directive 2001/42 must be interpreted as meaning that a regulatory order, such as that at issue in the main proceedings, containing various provisions on the installation of wind turbines which must be complied with when administrative consent is granted for the installation and operation of such installations comes within the notion of 'plans and programmes', within the meaning of that directive. 


\section{On the EU Full System of Remedies: The Zoskupenie VLK II Case}

Judgment of the Court (Grand Chamber) of 8 November 2016 in Case C-243/15 - Lesoochranárske zoskupenie VLK

\section{Subject Matter}

This case concerns a preliminary reference made by the Supreme Court of the Slovak Republic in a case between the forest protection association called Lesoochranárske zoskupenie VLK and the district authority of Trenčín, Slovakia. The national proceedings concerns the organisation's request to be accorded the status of party to the administrative procedure relating to an application for authorization of a project to construct an enclosure for the purpose of extending a game park on a protected site. Such a status would ensure to the organization access to justice to challenge the authorization if granted. As the solution of the dispute turned around the interpretation of the Habitats Directive read in light of the Aarhus Convention, the national court decided to stay the proceedings and refer the matter to the Court of Justice.

\section{Key Findings}

57 As the Advocate General has noted, in essence, in point 80 of her Opinion, decisions adopted by the national authorities which fall within the scope of Article 6(3) of Directive 92/43 and do not relate to an activity listed in Annex I to the Aarhus Convention are envisaged in Article 6(1) (b) of that convention and therefore fall within the scope of Article 9(2) thereof in so far as they involve assessment by the competent authorities, before any authorisation of an activity, as to whether that activity, in the circumstances of the case, is likely to have a significant effect on the environment.

59 Consequently, those organisations must necessarily be able to rely in legal proceedings on the rules of national law implementing EU environmental law and the rules of $\mathrm{E} U$ environmental law having direct effect (see, by analogy, in respect of Article 10a of Directive 85/337, judgment of 15 October 2015, Commission v Germany, C-137/14, EU:C:2015:683, paragraph 92).

73 In the light of the foregoing, the answer to the question referred is that, inasmuch as Article 47 of the Charter, read in conjunction with Article 9(2) and (4) of the Aarhus Convention, enshrines the right to effective judicial protection, in conditions ensuring wide access to justice, of the rights which an environmental organisation meeting the conditions laid down in Article 2(5) of that convention derives from EU law, in this instance from Article 6(3) of Directive 92/43, read in conjunction with 
Article 6(1)(b) of that convention, it must be interpreted as precluding, in a situation such as that at issue in the main proceedings, an interpretation of rules of national procedural law to the effect that an action against a decision refusing such an organisation the status of party to an administrative procedure for authorisation of a project that is to be carried out on a site protected pursuant to that directive does not necessarily have to be examined during the course of that procedure, which may be definitively concluded before a definitive judicial decision on possession of the status of party is adopted, and is automatically dismissed as soon as that project is authorised, thereby requiring that organisation to bring an action of another type in order to obtain that status and to secure judicial review of compliance by the competent national authorities with their obligations stemming from Article 6(3) of that directive.

\section{Do's and Don'ts as Regarded Protected Sea Turtles in Greece}

Judgment of the Court (Fourth Chamber) of 10 November 2016 in Case C-504/14 - Commission v Hellenic Republic

\section{Subject Matter}

This infringement procedure brought against Greece concerns the infringement of the Habitats Directive as regards the protection of the priority species Caretta caretta, a sea turtle, located in the Natura 2000 called the Kyparissia area. The Commission contested the authorization of certain human activities in line with national law, as well as and the lack of (effective) enforcement measures against other activities prohibited under national law.

\section{Key Findings}

55 By confining itself (i) to bringing criminal proceedings against the executives of the company that built the roads in question and imposing administrative penalties on that company and (ii) to claiming, before the national courts, that the roads concerned are illegal and must be removed, the Hellenic Republic has failed to fulfil the specific obligation imposed on it by Article 6(2) of Directive 92/43 (see, by analogy, judgment of 9 November 1999, Commission v Italy, C-365/97, EU:C:1999:544, paragraph 109).

57 By failing to take provisional measures for the protection of that area in order to restrict use of the thoroughfares at issue until the conclusion of the above-mentioned court proceedings concerning the legality and 
possible closure of those thoroughfares, when, as the Advocate General has noted at point 77 of her Opinion, there is nothing to suggest that such measures would not be possible either for practical reasons or for reasons relating to EU law, the Hellenic Republic has failed to fulfil its obligations under Article 6(2) of Directive 92/43.

114 That being the case, it should be declared that:

- by tolerating the construction of houses in Agiannaki in 2010, the use, without a sufficient regulatory framework, of other houses in Agiannaki which were built in 2006 and the commencement of building works relating to around 50 dwellings located between Agiannaki and Elaia, and by authorising in 2012 the construction of three holiday houses in Vounaki;

- by tolerating the development of access routes to the beach in the Kyparissia area, namely the opening up of five new roads to Agiannaki beach and the asphalting of certain existing roads and thoroughfares;

- by failing to take adequate measures to enforce the prohibition on wild camping close to the beaches at Kalo Nero and Elaia;

- by failing to take the measures necessary to restrict the operation of bars between Elaia and Kalo Nero, on the breeding beaches of the Caretta caretta sea turtle, and by failing to ensure that the various forms of pollution caused by those bars do not disturb that species;

- by failing to take the measures necessary to reduce, within the Kyparissia area, the furniture and various structures found on the breeding beaches of the Caretta caretta sea turtle and by authorising the construction of a platform near the Messina Mare Hotel;

- by failing to take the measures necessary so as to ensure that the light pollution affecting the breeding beaches of the Caretta caretta sea turtle in the Kyparissia area is adequately curtailed; and

- by failing to take the measures necessary so as to ensure that fishing in the waters off the breeding beaches of the Caretta caretta sea turtle in the Kyparissia area is adequately curtailed, the Hellenic Republic has failed to fulfil its obligations under Article 6(2) of Directive $92 / 43$.

Accordingly, that provision is relevant only when the competent national authorities grant authorisation for a project, as that authorisation must in such a case be preceded by an appropriate assessment of the implications of the project for the site concerned.

122 Consequently, Article 6(3) of Directive 92/43 does not apply in respect of any action whose implementation was subject to authorisation but 
which was carried out without authorisation and thus unlawfully. That being the case, there can in this regard be no finding of failure to fulfil obligations on account of an infringement of Article 6(3).

141 A collection of legal instruments does not constitute a comprehensive legislative and regulatory framework when those instruments do not prevent breaches of the prohibition on deterioration laid down in Article 6(2) of Directive 92/43 or when the instruments must regularly be supplemented so that the protection required by Article 12 of the directive can be ensured.

149 In those circumstances, the Court finds that, by failing to adopt a comprehensive, coherent and strict legislative and regulatory framework for the protection of the Caretta caretta sea turtle in the Kyparissia area, the Hellenic Republic has failed to fulfil its obligations under Article 12(1)(b) and (d) of Directive 92/43.

157 As regards the alleged infringement of the prohibition on disturbance of protected species, laid down in Article 12(1)(b) of Directive 92/43, it should be stated that the infringements of Article 6(2) of the directive, as found in paragraph 114 of this judgment, all constitute prohibited disturbances of the Caretta caretta sea turtle.

\section{On Whether 'Roll Cores' are Covered by the Packaging and Packaging Waste Directive}

Judgment of the Court (Third Chamber) of 10 November 2016 in Joined Cases C-313/15 and C-530/15 - Eco-Emballages $S A$ and Others

\section{Subject Matter}

This case concerns two requests for a preliminary ruling coming from two France courts about the meaning of the concept of 'packaging' under the Packaging and Packaging Waste Directive. These question arose in cases in which the party to the proceedings disagreed about the fact that under Commission Directive 2013/2/EU, amending Annex I to the Packaging and Packaging Waste Directive, and French law implementing such EU legal framework, roll cores in the form of rolls tubes or cylinders, around which flexible material is wound and sold to consumers, constitute 'packaging' within the meaning of the Packaging and Packaging Waste Directive.

\section{Key Findings}

25 It must next be recalled that, in order to constitute packaging within the meaning of Article 3(1) of Directive 94/62, an article must (i) fulfil the 
two conditions set out in the first and second subparagraphs of Article 3(1) of Directive 94/62 (see, to that effect, judgment of 29 April 2004, Plato Plastik Robert Frank, C-341/01, EU:C:2004:254, paragraph 47) and (ii) meet the criteria set out in the third subparagraph of Article 3(1) of that directive.

37 It follows from the foregoing that Article 3(1) of Directive 94/62 must be interpreted as meaning that roll cores in the form of rolls, tubes and cylinders, around which flexible products are wound and sold to consumers, constitute 'packaging', within the meaning of that provision.

\section{On Triangular Situations and Legal Finality}

Judgment of the Court (First Chamber) of 17 November 2016 in Case C-348/15 - Stadt Wiener Neustadt

\section{Subject Matter}

This case concerns a preliminary ruling stemming from a complex legal dispute involving three public authorities and one undertaking. The dispute arose when the Government for the Land of Lower Austria refused to establish whether a waste management installation operating on the territory of the city of Wiener Neustadt should be subjected to an environmental impact assessment. The permit for operating such installation had been granted by the mayor of Wiener Neustadt prior to the entry of Austria to the European Union. Differently, the authorization from the First Minister for the Land of Lower Austria to increase the processing capacity from 9900 tonnes per annum to 34000 tonnes, had been granted in 2002 without performing an environmental impact assessment. Twelve years later, the Austrian Environmental Ombudsman, noting this lacuna, requested the Government of the Land for Lower Austria to perform such an assessment. Once the Government refused to do so, the city of Wiener Neustadt added the administrative court seeking for the annulment of such a decision. Once the dispute reached the Austrian Supreme Administrative Court, this decided to stay the proceedings and ask the Court of Justice for guidance as regards first whether Directive 85/337/EEC, the old Environmental Liability Directive, covers a national provision under which projects the development consent of which is no longer at risk of annulment at 19 August 2009, such as that in the main proceeding, shall be regarded as having been granted in accordance with the Austrian Law on the environmental impact assessment (UVP-G 20oo). Secondly, the national court wished to know whether such a legislative provision may be justified under the $E U$ law principles of legal certainty and legitimate expectations. 


\section{Key Findings}

36 Eulawdoesnotprecludenationallegislation which,incertaincases, permits the regularisation of operations or measures which are unlawful in thelight of EU law. However, such a possibility is subject to the condition that it does not offer the persons concerned the opportunity to circumvent EU law or dispense with applying it, and that it should remain the exception (see judgment of 3 July 2008, Commission v Ireland, C-215/o6, EU:C:2008:380, point 57).

43 However, a national provision under which projects in respect of which the consent can no longer be subject to challenge before the courts, because of the expiry of the time limit for bringing proceedings laid down in national legislation, are purely and simply deemed to be lawfully authorised as regards the obligation to assess their effects on the environment, which it is for the referring court to ascertain, is not compatible with that directive

48 It follows from the foregoing that, if a national provision prevents, on expiry of a given time limit, any action for a remedy of a breach of the obligation to assess effects on the environment set out in Article 2(1) of Directive 85/337 while the time limit for bringing proceedings placed on the action for a remedy has not expired, it would be incompatible with $\mathrm{EU}$ for that reason as well.

\section{On the Linkage between the Right of Access to 'Environmental Information' and Commercial Interests (I)}

Judgment of the Court (Fifth Chamber) of 23 November 2016 in Case C-673/13P European Commission $v$ Stichting Greenpeace Nederland and PAN Europe

\section{Subject Matter}

This appeal case originated from the request, made on 20 December 2010, by two ENGOs, Stichting Greenpeace Nederland ('Greenpeace Nederland') and Pesticide Action Network Europe (PAN Europe) made a request, on the basis of Regulation Nos 1049/2001 and 1367/2006 for access to several documents relating to the initial authorisation for the placing of glyphosate on the market as an active substance, granted under Directive 91/414. The German Government, which had issued a draft report under Directive 91/414, first, and the Commission after, both refuted access to the requested document based on Article 4(2) of Regulation No 1049/2001, on the ground that that document contained confidential information relating to the intellectual property rights of the applicants which had sought the 
inclusion of glyphosate in Annex I to Directive 91/414. The General Court had annulled the Commission's decision on the ground that the exception to the right of access designed to protect the commercial interests of a natural or legal person, laid down in the first indent of Article 4(2) of that regulation must, in the present case, be discounted since the information requested related to emissions into the environment within the meaning of the first sentence of Article 6(1) of Regulation No 1367/2006. According to the Commission, the General Court erred in its interpretation of the term information [which] relates to emissions into the environment'within the meaning of the first sentence of Article 6(r) of Regulation No 1367/2006 and bought an appeal before the Court of Justice.

\section{Key Findings}

55 Under those circumstances, the General Court did not err in law, in paragraphs 49 and 53 of the judgment under appeal, in concluding that the first sentence of Article 6(1) of Regulation No 1367/2006 and the concept of 'information ... [which] relates to emissions into the environment' must not be interpreted strictly.

70 In the light of the above considerations, the General Court did not err in law in considering, in paragraphs 54 to 56 of the judgment under appeal, that the concept of 'information [which] relates to emissions into the environment' within the meaning of that provision is not limited to information concerning emissions emanating from certain industrial installations.

76 Consequently, the Commission is wrong to maintain that, by considering that the document at issue included 'information ... [which] relates to emissions into the environment', the General Court erred in law, on the ground that that document did not contain any information on the nature and quantity of the emissions actually released into the environment when the product at issue is used.

81 On the other hand, while, as set out in paragraph 55 of the present judgment, it is not necessary to apply a restrictive interpretation of the concept of 'information [which] relates to emissions into the environment', that concept may not, in any event, include information containing any kind of link, even direct, to emissions into the environment. If that concept were interpreted as covering such information, it would to a large extent deprive the concept of 'environmental information' as defined in Article 2(1)(d) of Regulation No 1367/2006 of any meaning. Such an interpretation would deprive of any practical effect the possibility, laid down in the first indent of Article 4(2) of Regulation No 1049/2001, for the institutions to refuse to disclose environmental 
information on the ground, inter alia, that such disclosure would have an adverse effect on the protection of the commercial interests of a particular natural or legal person and would jeopardise the balance which the EU legislature intended to maintain between the objective of transparency and the protection of those interests. It would also constitute a disproportionate interference with the protection of business secrecy ensured by Article 339 TFEU.

82 It follows from the above that, by holding, in paragraph 53 of the judgment under appeal, that it is sufficient that information relates, in a sufficiently direct manner, to emissions into the environment in order for that information to fall within the scope of 'information [which] relates to emissions into the environment' within the meaning of the first sentence of Article 6(1) of Regulation No 1367/2006, the judgment under appeal is vitiated by an error of law.

\section{On the Linkage between the Right of Access to 'Environmental Information' and Commercial Interests (II)}

Judgment of the Court (Fifth Chamber) of 23 November 2016 in Case C-442/14 - Bayer CropScience SA-NV and Stichting De Bijenstichting v College voor de toelating van gewasbeschermingsmiddelen en biociden

\section{Subject Matter}

This case concerns a preliminary ruling stemming from a proceedings between Bayer CropScience BV ('Bayer') and Stichting De Bijenstichting ('Bijenstichting' which aims at protecting the well-being of bees) and the College voor de toelating van gewasbeschermingsmiddelen en biociden (the Plant Protection Products and Biocides Approval Board, 'the ств'). The national proceedings concerns the decision of 18 March 2013 by which the ств, in essence, partially upheld Bijenstichting's request for disclosure of documents submitted by Bayer during procedures for the authorisation of the placing on the Dutch market of certain plant protection products and biocides, based on the active ingredient imidacloprid, which, inter alia, has an insecticide effect. This decision had been taken on the basis of the factual information relating to actual emissions of plant protection products or biocides into the environment should be regarded as information on emissions into the environment', within the meaning of the second subparagraph of Article 4(2) of Directive 2003/4. Both Bijenstichting and Bayer challenged the decision of the ств of 18 March 2013 before the referring court, the College van Beroep voor het bedrijfsleven (Administrative Court of Appeal for Trade and Industry, Netherlands). 
This court decided to ask several preliminary questions about the meaning of 'information on emissions into the environment', within the meaning of the second subparagraph of Article 4(2) of Directive 2003/4.

\section{Key Findings}

49 In the light of the above, the answer to the first two questions is that Article 4(2) of Directive 2003/4 must be interpreted as meaning that the fact that the applicant for authorisation to place a plant protection product or biocide on the market, did not, during the procedure for obtaining that authorisation, request that information submitted under that procedure be treated as confidential on the basis of Article 14 of Directive 91/414, Article 19 of Directive 98/8 or Article 33(4) and Article 63 of Regulation No 1107/2009 does not preclude the competent authority, which has received, following the closure of that procedure, a request for access to the information submitted on the basis of Directive 2003/4 by a third party, from examining the applicant's objection to that request for access and refusing it, if necessary, pursuant to point (d) of the first subparagraph of Article 4(2) of that directive on the ground that the disclosure of that information would adversely affect the confidentiality of commercial or industrial information.

$5^{8}$ It follows that, contrary to what, inter alia, Bayer, the German Government and the European Commission submit, it is not necessary to apply a restrictive interpretation of 'emissions into the environment' and 'information on emissions into the environment' within the meaning of the second subparagraph of Article 4(2) of Directive 2003/4.

81 In the light of all of the above, 'emissions into the environment' within the meaning of the second subparagraph of Article 4(2) of Directive 2003/4 must be interpreted as including, inter alia, the release into the environment of products or substances such as plant protection products or biocides and substances contained in those products, to the extent that that release is actual or foreseeable under normal or realistic conditions of use.

96 In the light of all the above, it is necessary to consider that 'information on emissions into the environment' covers information concerning the nature, composition, quantity, date and place of the 'emissions into the environment' of plant protection products and biocides and substances contained therein, and data concerning the medium to long-term consequences of those emissions on the environment, in particular information relating to residues in the environment following application of the product in question, and studies on the measurement of the substance's drift during that application, whether those data come from studies 
performed entirely or in part in the field or from laboratory or translocation studies.

97 Moreover, it must be stressed that, contrary to what, in essence, Bayer and the German Government claim, such an interpretation of the second subparagraph of Article 4(2) of Directive 2003/4 does not disregard either Articles 16 and 17 of the Charter of Fundamental Rights of the European Union ('the Charter') as regards freedom to conduct a business and the right to property, or Article 39(3) of the TRIPs Agreement which ensures the confidentiality of undisclosed data submitted by an applicant for authorisation to place pharmaceutical or chemical products on the market. Nor does it deprive of its effectiveness Article 63 of Regulation No $1107 / 2009$ which, in paragraph 2 thereof, lists data normally deemed to undermine, inter alia, the protection of commercial interests and in respect of such information, any person may, pursuant to paragraph 1 of that article, request that it is to be treated as confidential.

\section{On the Linkage between the EIA Directive, the Birds Directive and the Habitats Directive}

Judgment of the Court (Fifth Chamber) of 24 November 2016 in Case C-461/15 - European Commission $v$ Kingdom of Spain

\section{Subject Matter}

This case concerns an infringement procedure against Spain for failure to protect the nature reserve of Campinas de Sevilla, a Natura 2000 site, against the negative effects of a project about the building of a high-speed railway line between Seville and Almeía. According to the Commission, Spain had failed to comply with the Environmental Impact Assessment Directive, the Birds Directive and the Habitats Directive.

\section{Key Findings}

61 It follows that the complaint alleging breach of Article 3 of Directive $85 / 337$ must be rejected

101 It follows from all the foregoing considerations that, by failing to take appropriate steps to avoid, in the SPA 'Campiñas de Sevilla', the deterioration of natural habitats and the habitats of species as well as disturbance of the species for which that area was established, the Kingdom of Spain failed, in respect of the period before $29 \mathrm{July} 2008$, to fulfil its obligations under Article 4(4) of the Birds Directive and, with regard to the period 
after that date, has failed to fulfil its obligations under Article 6(2) of the Habitats Directive.

\section{On the Meaning of Annex I EIA Directive as Regards Three Different Kinds of Road Constructions}

Judgment of the Court (Sixth Chamber) of 24 November 2016 in Case C-645/15 - Bund Naturschutz in Bayern eV

\section{Subject Matter}

This case concerns a request for a preliminary ruling made by the Bavarian Higher Administrative Court, Germany, during a case between, among others, Bund Naturschutz in Bayern, an environmental association, and the Land of Bavaria. This dispute concerned the legality of the decision taken by the latter to approve the development of certain parts of a road within the municipal area of the City of Nuremberg, without having carried out an environmental impact assessment. As the dispute involved interpreting the Directive as regards the meaning of the concept of 'project' in relation to the kind of development works at stake, the national court decided to ask for guidance to the Court of Justice.

\section{Judgment}

1. Point 7 (c) of Annex I to Directive 2011/92/EU of the European Parliament and of the Council of 13 December 2011 on the assessment of the effects of certain public and private projects on the environment cannot be interpreted to the effect that it covers a road development project which, whilst it concerns, as in the case before the referring court, a stretch of road that is under $10 \mathrm{~km}$ in length, consists in the widening or development of an existing road with four or more lanes.

2. Point 7 (b) of Annex I to Directive 2011/92 must be interpreted as meaning that 'express roads' for the purposes of that provision are roads whose technical characteristics are those set out in the definition in point II.3 of Annex II to the European Agreement on Main International Traffic Arteries (AGR), signed in Geneva on 15 November 1975, even if those roads do not form part of the network of main international traffic arteries or are located in urban areas.

3. The concept of 'construction' for the purposes of point 7 (b) of Annex I to Directive 2011/92 must be interpreted as referring to the carrying-out of works not previously existing or to the physical alteration of existing installations. In order to determine whether such an alteration may be 
regarded as equivalent, because of its scale and the manner in which it is carried out, to such construction, the referring court must take account of all the characteristics of the work concerned and not only of its length or of the fact that its initial route is retained.

\section{On Whether Plant Breeders are Individually Concerned under Article 263(4) TFEU}

Judgment of the Court (Sixth Chamber) of 24 November 2016 in Joined Cases C-408/15P and C-409/15 $\mathrm{P}$ - Ackermann Saatzucht GmbH \& Co. KG and Others

\section{Subject Matter and Judgment}

This case concerns two appeals brought by certain German and Dutch plant breeding undertakings, among which Ackermann Saatzucht GmbH, against the judgments the General Court dismissing the appeals aiming at invalidating Regulation (EU) No 511/2014 on compliance measures for the uses $f$ the Nagoya Protocol on Access to Genetic Resources and the Fair and Equitable Sharing of Benefits Arising from their Utilisation in the Union. The applicants aimed at being recognized to have standing under Article 263(3) TFEU, as they are directly and individually concerned by the Regulation, something that the General Court dismissed.

The Court dismissed the appeals

\section{Editor's Appraisal of the Reported Case Law}

The period taken into consideration under this appraisal was a relatively busy one. Given the length of the overview of judgments section, I will limit this appraisal to the three themes that dominated the workload of the Court of Justice in the reported period. First, several judgments concerned the validity of the system for allocation of free allowances under the ETS Directive. ${ }^{2}$ These cases are all related to the Borealis case, Joined Cases C-191/14, C-192/14, C-389/14 and C-391/14 to C-393/14 - Borealis Polyolefine GmbH and Others, discussed in the appraisal published in JEEPL 2016/3-4, basically confirming that the Commission's system for calculating the allocation of free emission allowances under

2 Besides Case C-180/15 Borealis and Others and Case C-506/14 Yara Suomi and Others reported above, other four Orders of the Court related to this theme: C-551/14P; Joined Cases C-369/15 to $\mathrm{C}-372 / 15$; Case $\mathrm{C}-564 / 14 \mathrm{P}$; and Case $\mathrm{C}-565 / 14 \mathrm{P}$. 
Decision 2011/278/EU is valid while that under Article 4 of, and Annex II to, Decision $2013 / 448 / \mathrm{EU}$ is invalid. Remarkably, the Commission has still not published measures aiming at solving the lacuna that the entry into force of the invalidity declaration, set at the 1st of March 2017, would cause.

Second, several judgments of the Court of Justice concerned authorization procedures and their compatibility with the EIA Directive, the Birds Directive and/or the Habitats Directive. The Bund Naturschutz in Bayern Case, the Stadt WienerNeustadtCase, the Patrice D'Outremont and Others Case and the Commissionv Spain Case all show that the Court of Justice is willing to stretch the boundaries of the EIA Directive in order to protect the environment. However, the case-law is also showing the limits of expansive interpretation. Indeed, in the Bund Naturschutz in Bayern Case the Court of Justice refuted to interpret the Directive so as to cover all enlargements of existing roads to four or more lanes by means of the regime envisaged under Article 2(1) and 4(1) of the Directive. As Article 7(c) of Annex I to the Directive refers only to enlargement projects with a continuous length of $10 \mathrm{~km}$ or more, teleological interpretation cannot be used to change the will of the Eu legislature as evident from the letter and the system of the Directive.

When such an explicit limitation is not present, things seem different as shows by the Stadt Wiener Neustadt Case. The Stadt Wiener Neustadt Case shows the willingness of the Court to impose an obligation to perform an environmental impact assessment even after the elapsing of fourteen years from the date in which a project for the enlargement of the processing capacity of a waste management installation had been authorized. Legal certainty and legitimate expectations do not justify national provisions considering such authorizations as being granted in conformity with the national law implementing the Directive. From an environmental perspective, this judgment can be considered a welcome development. Yet, from the perspective of legal certainty, a similar conclusion cannot be easily reached. Indeed, hidden in the name of the parties of the case, we can see a dispute in which a public authority relies on the EIA Directive to the detriment of a private party. This is a typical Wells-like situation in which the private party must suffer the merely negative consequences of the fact that another (legal) person relied on the direct effect of Article 2(1) of the EIA Directive against the state. ${ }^{3}$ Likewise in the Salzburger Flughafen Case, ${ }^{4}$ another case coming from Austria, here the party relying on the EIA Directive is a public authority. Albeit implicitly, the Stadt Wiener

3 Case C-201/02 The Queen, on the application of Delena Wells $v$ Secretary of State for Transport, Local Government and the Regions ECLI:EU:C:2004:12.

4 Case C-244/12 Salzburger Flughafen GmbH v Umweltsenat ECLI:EU:C:2013:203. 
Neustadt Case seems to confirm that such a difference in comparison to the Wells Case does not stand in the way of direct effect. It is a pity that the Court established a duty to perform an environmental impact assessment without explicitly discussing the linkage between the Salzburger Flughafen Case and the Stadt Wiener Neustadt Case. Similarly, this duty was established without explicitly discussing the issue that the authorization under scrutiny had been granted, in first instance, by the Stadt Wiener Neustadt itself, an element that makes the question rise on how we have to understand the concept of state under Eu law. Cases such as Marshall ${ }^{5}$ and Fra-bo ${ }^{6}$ show that this concept is a broad one, but cases such as Salzburger Flughafen and Stadt Wiener Neustadt suggest that it is not an unitary concept. The meaning of this concept is far from being crystallized and therefore new developments can be expected. A corollary to this question is that concerning the value that can still be attributed to the prohibition of inverse vertical direct effect. Is this prohibition still relevant, especially when we consider that it seems that it can be easily bypassed by fragmenting the concept of state? ${ }^{7}$ This question becomes particularly relevant when we consider the Salzburger Flughafen and Stadt Wiener Neustadt cases in conjunction with the Fratelli Costanzo one,${ }^{8}$ in which the Court established that the duty of recognizing direct effect to sufficiently clear and unconditional EU law provisions applies not only to courts, but to public authorities as well. Regardless of whether a marginalization of the prohibition to inverse vertical direct effect is seen as a positive or a negative development, it should not be a silent one.

Finally, the third theme dealt with by the Court of Justice in the cases reported in this appraisal concerns judicial protection under EU environmental law. The judgments of the Court in Ackermann Saatzucht and Others will probably be seen a new missed opportunity for the Court of Justice to allow for public interest litigation. Once again, private parties were denied access to justice under Article 263 TFEU in light of the 'directly and individually concerned' criteria. The acquired binding force of Article 47 of the Charter does not alter the interpretation given by the Court to these criteria in its long standing

5 Case 152/84 M.H. Marshall $v$ Southampton and South-West Hampshire Area Health Authority (Teaching) ECLI:EU:C:1986:84.

6 Case C-171/11 Fra.bo SpA v Deutsche Vereinigung des Gas- und Wasserfaches eV (DVGW) ECLI:EU:C:2012:453.

7 To this extent as regards the L. Squintani, \& H.H.B. Vedder, (2014). Towards Inverse Direct Effect?: A Silent Development of a Core European Law Doctrine. Review of European Community and International Environmental Law (RECIEL), 23(1), 144-149. DOI: 10.111//reel.12063.

8 Case 103/88 Fratelli Costanzo SpA v Comune di Milano ECLI:EU:C:1989:256. 
case law. Yet, the judgment in Lesoochranáske zoskupenie VLK shows that this provision, likewise Article $19 \mathrm{TEU}$ and Article 9 of the Aarhus Convention, is not meaningless. As this latter judgment will be further discussed in the annotation of Matthijs van Wolferen, I limit myself in mentioning that this case shows a progressively more a more clear attempt of the Court of Justice to bypass the limitation of its own imposed strict interpretation of Article 263(4) TFEU by means of a broad access to justice at national level, triggering the applicability of Article $267 \mathrm{TFEU}$, a path that the Commission is contributing to shape, as explained by its civil servants during the Workshop reported in the previous number of this journal. Whether this development should be seen as a satisfactory one from the perspective of public interest litigation in general and environmental protection in particular is something that deserves further discussion and deeper investigation. To Van Wolferen the pleasure to open the dance. 